Available online on 15.01 .2016 at http://jddtonline.info
Journal of Drug Delivery and Therapeutics
An International Peer Reviewed Journal
Open access to Pharmaceutical and Medical research
(C) 2016, publisher and licensee JDDT, This is an Open Access article which permits unrestricted noncommercial use, provided the original
work is properly cited

\title{
RESEARCHARTICLE
}

\section{DEVELOPMENT AND OPTIMIZATION OF CHRONOPHARMACEUTICAL DRUG DELIVERY SYSTEM FOR ASTHMA}

\author{
${ }^{1}$ Shilpa Praveen Chaudhari*, ${ }^{1}$ Pallavi M Chaudhari, ${ }^{2}$ Sandeep Narawane \\ ${ }^{1}$ Dept. of Pharmaceutics, Padmashree Dr. D.Y. Patil College of Pharmacy, Akurdi, Pune-44, India \\ ${ }^{2}$ Marathwada Mitra Mandal's College of Pharmacy, Thergaon, Pune-33, India \\ *Corresponding Author's Email: shilpapchaudhari78@yahoo.com
}

Received 18 Nov 2015; Review Completed 08 Dec 2015; Accepted 12 Dec 2015, Available online 15 Jan 2016

\begin{abstract}
The present research was designed to increase bioavailability and solubility of Montulokast Sodium by formulating Chrono pharmaceutical delivery system. In the present study firstly immediate release core tablets were prepared by direct compression using Response Surface Methodology with different superdisintegrants, diluents and surfactants to release drug faster. In that formulation containing cross carmellose sodium and Poloxomer-188 with highly soluble lactose gave $95 \%$ release in 30 minutes with optimum pre \& post compression characteristics. Chronopharmaceutical Drug delivery formulations were then prepared by press coating using polymers as Xanthan gum, Polyox, HPMC \& Ethyl Cellulose alone and in combination. The results revealed that combinations of these polymers give better lag time rather than using a single polymer. Thus it can be concluded that combining hydrophilic and hydrophobic polymer can be done to achieve the respected lag time required for pulsatile release.
\end{abstract}

Keywords: Montelukast Sodium, Chronopharmaceutical Drug Delivery System.

\section{INTRODUCTION}

Traditionally, drug delivery systems have focused on constant/sustained drug output with the objective of minimizing peaks and valleys of drug concentrations in the body to optimize drug efficacy and to reduce adverse effects. Diseases where a constant drug levels are not preferred, but needs a pulse of therapeutic concentration in a periodic manner acts as a push for the development of "Chronopharmaceutical Drug Delivery Systems" 1-2. The Montelukast Sodium is Leukotriene receptor antagonist used for the maintenance treatment of asthma, chronic asthma attacks and to relive symptoms of seasonal allergies.

Asthma is chronic inflammatory disease of the airways, characterized by hyper responsiveness to variety of stimuli. The role of circadian rhythm in the photogenesis and treatment of asthma indicates that airway resistance increases progressively at night in asthmatic patient. Circadian changes are seen in normal lung function, which reaches in low point in the early morning hours. The worsening of asthma at night, commonly referred to as Nocturnal Asthma (NA). A drug delivery system administered at bedtime but releasing drug during morning hours would be ideal in this case. Nocturnal Asthma is variable exacerbation of underlying asthma condition associated with increase in symptoms, need for medication, airway responsiveness, and/or worsening of lung function ${ }^{4}$.Press coated tablets (PCTs) gained wide interest 'claiming some advantages over regular and (pan-) coated tablets, such as to protect hygroscopic, light-sensitive or oxygen-labile drugs from environmental-atmospheric ill effects or decomposition of acid-labile drugs by gastric fluids; to separate incompatible drugs from each other; to achieve a sustained release in that the drug in the core is embedded in waxes or fats constituting a depot; to protect the gastric mucosa from irritation by certain drugs by using enteric coating material in the outer press-coating granules; or to achieve intermittent release by incorporating one portion of drug in the core and the other in the coat, separated by a film-coat or a second press-coat drawbacks of the press-coating technique are the multistep processes involved, and the requirement for reliable and reproducible central positioning of the core tablet within press-coated tablet $(\mathrm{PCT})^{5-8}$. The aim of the study was to develop and physico-chemically characterize pulsatile delivery tablet of Montelukast using different polymers. Montelukast has a biological half-life of about 2.5-5.5 hrs and $64 \%$ bioavailability. Development of pulse release formulation of Montelukast can be advantageous, that can provide specific lag time and increase compliancy of the dosage form towards patient's side. Asthma peak is more in 
early morning so it is not feasible to take tablet in midnight so pulsatile delivery is preferred one because this type of tablet should be taken after dinner which deliver drug immediately after a specified lag time about 4-5hrs. So drug may available (right time, right site) in blood circulation about 3 o'clock so it is available to protect from early morning asthma due to its 4-6 hrs. of half-life ${ }^{3}$.

So development of formulation consisted of a rapidly disintegrating core tablet press coated by a barrier layer consisting of varying concentrations of Xanthan Gum, Polyox303, Ethyl cellulose and Hydroxypropylmethyl cellulose. Ethylcellulose and hydrophilic polymers are used as a rate controlling polymer to achieve desired lag time.

\section{MATERIALS AND METHODS}

Drug Montelukast Sodium was obtained as gift sample from Shreya pharmaceutical ltd. Chikalthana,
Aurangabad, Maharashtra, India.Poloxomer-188, Poloxomer-407, Crosscarmalose sodium, Microcrystalline Cellulose, Sodium Starch Glycolate, Lactose, HPMC, Ethyl Cellulose, Xanthan Gum, Polyox were obtained from Research Lab Fine Chem.

\section{Preparation of core tablets:}

The inner-core tablets were prepared using direct compression to perform various release kinetics, depending upon the release mechanism involved. The composition of different formulations were prepared applying design expert software factorial design in which varying amounts of superdisintegrants, type of superdisintegrant, surfactant and diluents. Drug and the Excipients were homogeneously blended and subsequently compressed into tablet (6 mm Punch) using 12 station multi tooling rotary tablet punching machine The levels for the formulation design were as given in table 1 .

Table 1Formulation variables and their levels for core tablet optimization.

\begin{tabular}{|c|c|c|c|c|c|}
\hline Level & $\begin{array}{c}\mathbf{X}_{\mathbf{1}} \text {-Concentration } \\
\text { of Surfactant (mg) }\end{array}$ & $\begin{array}{c}\mathbf{X}_{\mathbf{2}^{-}} \text {-Concentration of } \\
\text { superdisintegrants (\%) }\end{array}$ & $\begin{array}{c}\mathbf{X}_{\mathbf{3}^{-}} \text {Type of } \\
\text { Surfactant }\end{array}$ & $\begin{array}{c}\mathbf{X}_{\mathbf{4}^{-}} \text {-Type of } \\
\text { superdisintegrants }\end{array}$ & $\begin{array}{c}\mathbf{X}_{\mathbf{5}^{-}} \text {-Type of } \\
\text { Diluent }\end{array}$ \\
\hline-1 & -1 & -1 & Poloxamer 407 (-1) & CCS(-1) & MCC(-1) \\
\hline+1 & 1 & 1 & Poloxamer 188 (1) & SSG $(1)$ & Lactose $(1)$ \\
\hline \multicolumn{2}{|l|}{ Dependent Variable } & $Y_{1}$ - Drug release in 30minutes \\
\cline { 2 - 6 } & $Y_{2}$-Disintegration Time (DT) \\
\hline
\end{tabular}

Table 2 summarizes the experimental runs, their factor combinations and the translation of the coded levels to the experimental units used in the study.

Table 2: Factor combinations as per the chosen experimental design

\begin{tabular}{|c|c|c|c|c|c|}
\hline Batch code & $\mathbf{X}_{\mathbf{1}}$ & $\mathbf{X}_{\mathbf{2}}$ & $\mathbf{X}_{\mathbf{3}}$ & $\mathbf{X}_{\mathbf{4}}$ & $\mathbf{X}_{\mathbf{5}}$ \\
\hline 1 & -1.000 & -0.800 & -1 & -1 & -1 \\
\hline 2 & 1.000 & -1.000 & -1 & 1 & 1 \\
\hline 3 & 0.210 & -0.040 & -1 & -1 & -1 \\
\hline 4 & -1.000 & 1.000 & -1 & -1 & 1 \\
\hline 5 & 0.160 & 1.000 & 1 & -1 & -1 \\
\hline 6 & 0.910 & 0.250 & -1 & 1 & 1 \\
\hline 7 & -1.000 & -1.000 & 1 & 1 & 1 \\
\hline 8 & 1.000 & 1.000 & 1 & 1 & 1 \\
\hline 9 & -1.000 & -1.000 & 1 & 1 & 1 \\
\hline 10 & 0.210 & -0.040 & -1 & 1 & -1 \\
\hline 11 & -1.000 & 1.000 & -1 & 1 & -1 \\
\hline 12 & 1.000 & -1.000 & 1 & -1 & -1 \\
\hline 13 & 0.160 & 1.000 & 1 & -1 & -1 \\
\hline 14 & 1.000 & -1.000 & 1 & -1 & -1 \\
\hline 15 & 0.910 & 0.250 & -1 & -1 & 1 \\
\hline 16 & -0.500 & 0.500 & 1 & 1 & 1 \\
\hline
\end{tabular}

\section{Formulation of Press coated tablet:}

Powder blend for press-coated tablet was prepared by dry blending together different compositions of the Ethyl cellulose, HPMC, Polyox WSR301, and Xanthan gum as shown in Table 3. These excipients were dry blended in different weight compositions using surface response design in order to get suitable polymer composition. This composition was dry blended until uniformly blended mixture was obtained. This mixture was then used for the preparation of press - coated tablet using direct compression method (10mm punch). 
Table 3: Formulation variables for press coated tablet optimization

\begin{tabular}{|c|c|c|c|}
\hline Level & $\begin{array}{c}\mathbf{X}_{1} \text {-Concentration of Ethyl } \\
\text { Cellulose }\end{array}$ & $\begin{array}{c}\mathrm{X}_{2} \text {-Concentration of } \\
\text { polymer }\end{array}$ & $\mathbf{X}_{3}$-Type of Polymers \\
\hline-1 & 0 & 50 & HPMC (10000) \\
\hline 0 & 75 & 100 & Xanthan gum(01000) \\
\hline \multirow[t]{4}{*}{+1} & \multirow[t]{4}{*}{150} & \multirow[t]{4}{*}{150} & Polyox (00100) \\
\hline & & & HPMC+ Polyox(-1-1-1-1-1) \\
\hline & & & HPMC+ Xanthan gum(00001) \\
\hline & & & Polyox+ Xanthan gum(00010) \\
\hline
\end{tabular}

Table 4: Formulation of Press coated tablet

\begin{tabular}{|c|c|c|c|}
\hline Formulation & $\begin{array}{c}\text { Factor-1 Concentrationof } \\
\text { polymer }\end{array}$ & $\begin{array}{c}\text { Factor-2 Concentration of } \\
\text { Ethyl cellulose }\end{array}$ & Factor-3 Types of Polymer \\
\hline 1 & -0.8 & -0.83481 & $\left\{\begin{array}{lllllll}0 & 0 & 1 & 0 & 0\end{array}\right\}$ \\
\hline 2 & -0.07 & -0.06 & 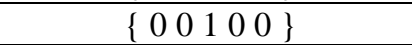 \\
\hline 3 & -1 & 0 & $\left\{\begin{array}{llllll}0 & 0 & 0 & 1 & 0\end{array}\right\}$ \\
\hline 4 & 0.971953 & -0.3 & $\left\{\begin{array}{lllllll}0 & 0 & 1 & 0 & 0\end{array}\right\}$ \\
\hline 5 & 0.960118 & -0.35 & $\left\{\begin{array}{llllll}0 & 1 & 0 & 0 & 0\end{array}\right\}$ \\
\hline 6 & 0 & 1 & $\left\{\begin{array}{lllll}0 & 0 & 0 & 1 & 0\end{array}\right\}$ \\
\hline 7 & -1 & -1 & $\left\{\begin{array}{lllll}-1 & -1 & -1 & -1 & -1\end{array}\right\}$ \\
\hline 8 & -0.55 & 0.56 & $\left\{\begin{array}{lllll}-1 & -1 & -1 & -1 & -1\end{array}\right\}$ \\
\hline 9 & -0.83 & -0.82 & $\left\{\begin{array}{lllllll}0 & 1 & 0 & 0 & 0\end{array}\right\}$ \\
\hline 10 & 0.53 & -0.54863 & $\left\{\begin{array}{lllll}-1 & -1 & -1 & -1 & -1\end{array}\right\}$ \\
\hline 11 & -1 & 1 & $\left\{\begin{array}{llllll}0 & 0 & 0 & 0 & 1\end{array}\right\}$ \\
\hline 12 & 0 & -1 & $\left\{\begin{array}{lllllll}0 & 0 & 0 & 1 & 0\end{array}\right\}$ \\
\hline 13 & 0.53 & -0.54863 & $\left\{\begin{array}{lllll}-1 & -1 & -1 & -1 & -1\end{array}\right\}$ \\
\hline 14 & -0.4 & 0.96767 & $\left\{\begin{array}{lllll}0 & 0 & 1 & 0 & 0\end{array}\right\}$ \\
\hline 15 & -0.55 & -0.56 & $\left\{\begin{array}{lllllll}0 & 0 & 0 & 0 & 1\end{array}\right\}$ \\
\hline 16 & 0.95 & -0.44 & $\left\{\begin{array}{llllll}1 & 0 & 0 & 0 & 0\end{array}\right\}$ \\
\hline 17 & -1 & 0.19 & $\left\{\begin{array}{llllll}0 & 1 & 0 & 0 & 0\end{array}\right\}$ \\
\hline 18 & 0.71 & 0.84 & $\left\{\begin{array}{lllllllll}0 & 1 & 0 & 0 & 0\end{array}\right\}$ \\
\hline 19 & 0.56 & 0.55 & $\left\{\begin{array}{llllll}0 & 0 & 0 & 0 & 1\end{array}\right\}$ \\
\hline 20 & 1 & 1 & $\left\{\begin{array}{lllll}-1 & -1 & -1 & -1 & -1\end{array}\right\}$ \\
\hline 21 & 1 & 0.623881 & $\left\{\begin{array}{llllll}1 & 0 & 0 & 0 & 0\end{array}\right\}$ \\
\hline 22 & 1 & 0 & $\left\{\begin{array}{llllll}0 & 0 & 0 & 1 & 0\end{array}\right\}$ \\
\hline 23 & 0.56 & 0.55 & $\left\{\begin{array}{llllll}0 & 0 & 0 & 0 & 1\end{array}\right\}$ \\
\hline 24 & -0.36 & 0.98 & $\left\{\begin{array}{lllllll}0 & 1 & 0 & 0 & 0\end{array}\right\}$ \\
\hline 25 & 0.17 & -1 & $\left\{\begin{array}{lllllll}0 & 1 & 0 & 0 & 0\end{array}\right\}$ \\
\hline 26 & -0.55 & -0.56 & $\left\{\begin{array}{llllll}0 & 0 & 0 & 0 & 1\end{array}\right\}$ \\
\hline 27 & -0.28 & 0.95 & $\left\{\begin{array}{lllll}1 & 0 & 0 & 0 & 0\end{array}\right\}$ \\
\hline 28 & -0.55 & 0.56 & $\{-1-1-1-1-1\}$ \\
\hline 29 & 1 & -1 & $\left\{\begin{array}{lllll}0 & 0 & 0 & 0 & 1\end{array}\right\}$ \\
\hline 30 & -0.86 & -0.79 & $\left\{\begin{array}{lllllll}1 & 0 & 0 & 0 & 0\end{array}\right\}$ \\
\hline 31 & 0.971953 & -0.3 & $\left\{\begin{array}{llllll}0 & 0 & 1 & 0 & 0\end{array}\right\}$ \\
\hline
\end{tabular}

\section{Evaluation of press coated tablets}

Core tablets and Press Coated Pulsatile Tablets were evaluated for following parameters as per their pharmacopoeial procedures.

Hardness test: It was determined using Monsanto hardness tester ${ }^{9-11}$.

Friability test: Ten tablets were initially weighed and transferred into Roche friabilator. The friabilator was operated at $25 \mathrm{rpm}$ for 4 minutes ${ }^{9-11}$.
Weight variation test: Ten tablets were selected randomly from each formulation and weighed individually to check for weight variation ${ }^{9-11}$.

In vitro drug release studies:

\section{(A) Core Tablets}

The in vitro drug release from core tablets was carried out using USP paddle apparatus at $50 \mathrm{rpm}$ and $37 \pm 0.5^{\circ} \mathrm{C}$. Phosphate buffer ( $\mathrm{pH}$ 6.8) was used as the dissolution medium. The samples were withdrawn at regular intervals and analyzed by UV spectrophotometer at $225 \mathrm{~nm}$ for the presence of the drug. Dissolution tests were performed in triplicate ${ }^{9-11}$. 


\section{(B) Press Coated Pulsatile Tablets}

The in vitro drug release from coated tablets was carried out using USP paddle apparatus at $50 \mathrm{rpm} . \mathrm{HCl}(0.1 \mathrm{~N})$ and phosphate buffer ( $\mathrm{pH}$ 6.8) were used as the dissolution medium. Initially tablets were subjected to dissolution in $0.1 \mathrm{HCl}$ for $2 \mathrm{~h}$ and after that media were changed to phosphate buffer ( $\mathrm{pH}$ 6.8). The samples were withdrawn at regular intervals and analyzed by UV spectrophotometer at $\mathbf{2 2 5} \mathbf{n m}$ for the presence of the drug. Dissolution tests were performed in triplicate.

\section{RESULT \& DISCUSSION:}

\section{Compatibility Studies}

In order to investigate the possible interactions between Montelukast Sodium and polymers and/or diluents, FTIR of Drug were carried out by using FTIR spectrophotometer (FTIR-8400S)as shown in Fig.1a, and b. FT-IR results proved that the drug was found to be compatible with excipients as wave numbers are almost similar for pure drug and also drug excipients mixture.

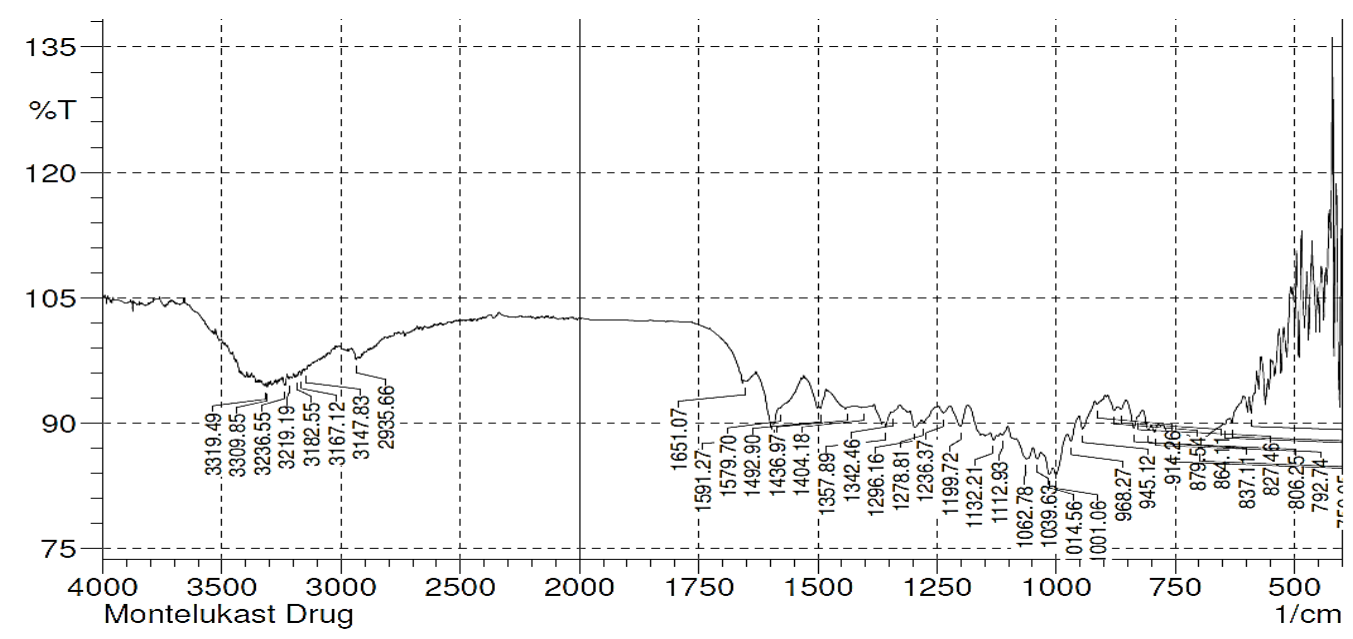

Figure 1a: IR spectrum of the Montelukast sodium Drug

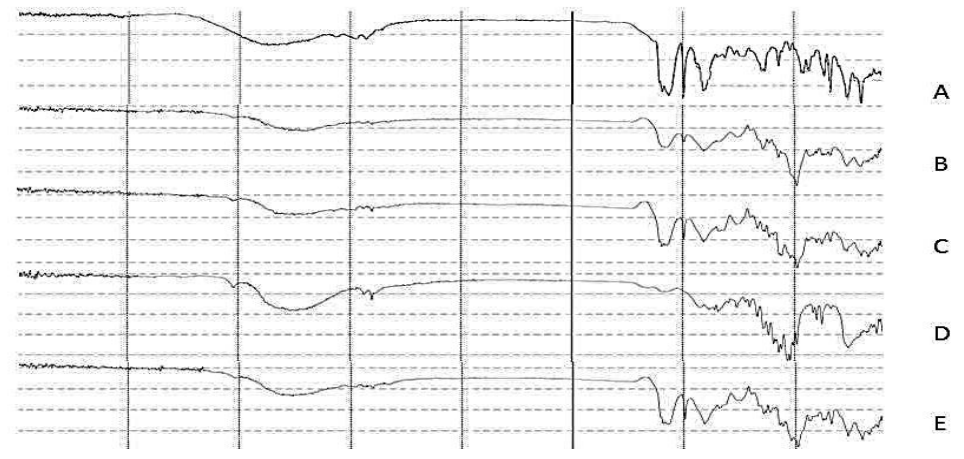

Figure1b: IR spectrum of A) Drug B) Drug+Sodium Starch Glycolate C) Drug+Cross Camallose Sodium D) Drug+Lactose E) Drug+Microcrystalline Cellulose.

\section{Precompression Parameters of Core Tablet Powder Blend}

Bulk density, tapped density, Hausner's ratio and carr's index given in the Table5.The angle of repose $(\theta)$ for all the formulation ranged from 19 to $25^{\circ}$ indicating good flow properties. The result of compressibility index was between 12 to 16 , which indicates good flow properties \& for Hausners ratio was near/less about 1.2 also supported the results of free flowing.

\section{Postcompression Parameters of Core Tablets}

The tablet hardness, friability, weight variation of all tablet formulations were found to be satisfactory and reproducible as observed from the data in Table 6 . The hardness of all the tablets was between 3 to $5 \mathrm{~kg} / \mathrm{cm}^{2}$. In the present study, the loss in total weight in friability test was in the range of 0.77 to $0.91 \%$ that indicates, the percentage friability for all the formulations was found below $1 \%$ indicating that friability $(\%)$ is within the acceptable limits. In weight variation test, the pharmacopoeia limit for the percentage deviation for tablets weighing more than50 $\mathrm{mg}$ is $\pm 7.5 \%$. The average percentage deviation of all tablet formulations was found to be within limit, and hence all formulations passed the test for uniformity of weight as per official requirement. 
Table5: Evaluation of directly compressible blends of core tablet

\begin{tabular}{|c|c|c|c|c|c|}
\hline Formulations & $\begin{array}{c}\text { Bulk } \\
\text { Density }\left(\mathrm{g} / \mathrm{cm}^{3}\right)\end{array}$ & $\begin{array}{c}\text { Tapped } \\
\text { Density }\left(\mathrm{g} / \mathrm{cm}^{3}\right)\end{array}$ & $\begin{array}{c}\text { Angle of } \\
\text { Repose }\left({ }^{0}\right)\end{array}$ & $\begin{array}{c}\text { Carrs index } \\
(\%)\end{array}$ & $\begin{array}{c}\text { Hausners ratio } \\
\text { (HR) }\end{array}$ \\
\hline F1 & 0.48 & 0.50 & 25.066 & 19.0 & 1.19 \\
\hline F2 & 0.55 & 0.60 & 21.65 & 16.6 & 1.20 \\
\hline F3 & 0.45 & 0.55 & 19.50 & 10.0 & 1.11 \\
\hline F4 & 0.55 & 0.66 & 21.03 & 16.6 & 1.20 \\
\hline F5 & 0.49 & 0.55 & 18.25 & 23.63 & 1.30 \\
\hline F6 & 0.50 & 0.60 & 19.9 & 16.6 & 1.20 \\
\hline F7 & 0.62 & 0.65 & 21.41 & 4.6 & 1.02 \\
\hline F8 & 0.50 & 0.55 & 19.69 & 18.0 & 1.21 \\
\hline F9 & 0.62 & 0.65 & 18.41 & 4.6 & 1.02 \\
\hline F10 & 0.45 & 0.48 & 22.50 & 10.0 & 1.11 \\
\hline F11 & 0.50 & 0.60 & 21.74 & 16.6 & 1.20 \\
\hline F12 & 0.45 & 0.50 & 19.13 & 18.0 & 1.21 \\
\hline F13 & 0.50 & 0.55 & 18.25 & 23.63 & 1.30 \\
\hline F14 & 0.45 & 0.50 & 22.13 & 18.0 & 1.21 \\
\hline F15 & 0.50 & 0.60 & 25.90 & 16.6 & 1.20 \\
\hline F16 & 0.45 & 0.50 & 27.74 & 18.0 & 1.21 \\
\hline
\end{tabular}

Table 6: Evaluation of Formulations of rapid release core tablet

\begin{tabular}{|c|c|c|c|c|c|c|}
\hline & $\begin{array}{c}\text { Hardness }\left(\mathrm{kg} / \mathrm{c}^{2}\right) \\
(\mathrm{n}=3)\end{array}$ & $\begin{array}{l}\text { Thickness(mm) } \\
\qquad(\mathrm{n}=3)\end{array}$ & $\begin{array}{l}\text { Diameter } \\
(\mathbf{m m})\end{array}$ & $\begin{array}{c}\text { Weight } \\
\text { variation }(\%)(n=20)\end{array}$ & $\begin{array}{l}\text { Disintegration } \\
\text { time (Sec.) }\end{array}$ & $\begin{array}{c}\text { Friability } \\
(\%) \\
(\mathbf{n}=10) \\
\end{array}$ \\
\hline F1 & $3.5 \pm 0.50$ & $2.64 \pm 0.012$ & $6.01 \pm 0.015$ & $101 \pm 0.67$ & 150 & 0.78 \\
\hline F2 & $4 \pm 0.50$ & $2.54 \pm 0.005$ & $6.00 \pm 0.010$ & $100 \pm 0.54$ & 21 & 0.66 \\
\hline F3 & $5 \pm 0.50$ & $2.60 \pm 0.010$ & $6.02 \pm 0.007$ & $102 \pm 0.66$ & 180 & 0.62 \\
\hline F4 & $3 \pm 0.50$ & $2.52 \pm 0.014$ & $6.00 \pm 0.015$ & $100 \pm 0.57$ & 18 & 0.87 \\
\hline F5 & $3 \pm 0.50$ & $2.65 \pm 0.009$ & $6.01 \pm 0.009$ & $100 \pm 0.88$ & 105 & 0.85 \\
\hline F6 & $3 \pm 0.50$ & $2.55 \pm 0.010$ & $6.01 \pm 0.015$ & $101 \pm 0.85$ & 22 & 0.80 \\
\hline F7 & $4 \pm 0.50$ & $2.57 \pm 0.012$ & $6.03 \pm 0.017$ & $99 \pm 1.15$ & 24 & 0.78 \\
\hline F8 & $5 \pm 0.50$ & $2.39 \pm 0.019$ & $6.02 \pm 0.013$ & $101 \pm 0.75$ & 25 & 0.67 \\
\hline F9 & $4 \pm 0.50$ & $2.5 \pm 0.020$ & $6.02 \pm 0.012$ & $98 \pm 1.3$ & 24 & 0.71 \\
\hline F10 & $3 \pm 0.50$ & $2.59 \pm 0.018$ & $6.00 \pm 0.014$ & $99 \pm 1.1$ & 180 & 0.69 \\
\hline F11 & $3 \pm 0.50$ & $2.69 \pm 0.019$ & $6.01 \pm 0.009$ & $99 \pm 1.2$ & 210 & 0.81 \\
\hline F12 & $4 \pm 0.50$ & $2.60 \pm 0.017$ & $6.02 \pm 0.015$ & $103 \pm 0.75$ & 255 & 0.77 \\
\hline F13 & $5 \pm 0.50$ & $2.504 \pm 18$ & $6.03 \pm 0.015$ & $101 \pm 0.60$ & 105 & 0.62 \\
\hline F14 & $4 \pm 0.50$ & $2.58 \pm 0.015$ & $6.01 \pm 0.008$ & $103 \pm 0.54$ & 255 & 0.70 \\
\hline F15 & $4 \pm 0.50$ & $2.61 \pm 0.012$ & $6.03 \pm 0.018$ & $103 \pm 0.56$ & 22 & 0.82 \\
\hline F16 & $5 \pm 0.50$ & $2.67 \pm 0.013$ & $6.02 \pm 0.015$ & $99 \pm 1.2$ & 31 & 0.84 \\
\hline
\end{tabular}

\section{In-Vitro Drug Release of core tablet}

For preparation of immediate release core tablets different superdisintegrants were used. In that Poloxomer-407 containing formulation shows immediate \& more release compared to other formulations. F4 formulation showed $95.49 \%$ drug release in 30 minas observed in Figure 2a.The result shows that lactose with superdisentegrants shows good disintegration \& dissolution properties as Lactose is highly water soluble \& along with superdisintegrants the release was very fast. Whereas in spray dried mucilagelactose, might have increased the viscosity \&could have acted as barrier for diffusion $\&$ faster dissolution. 


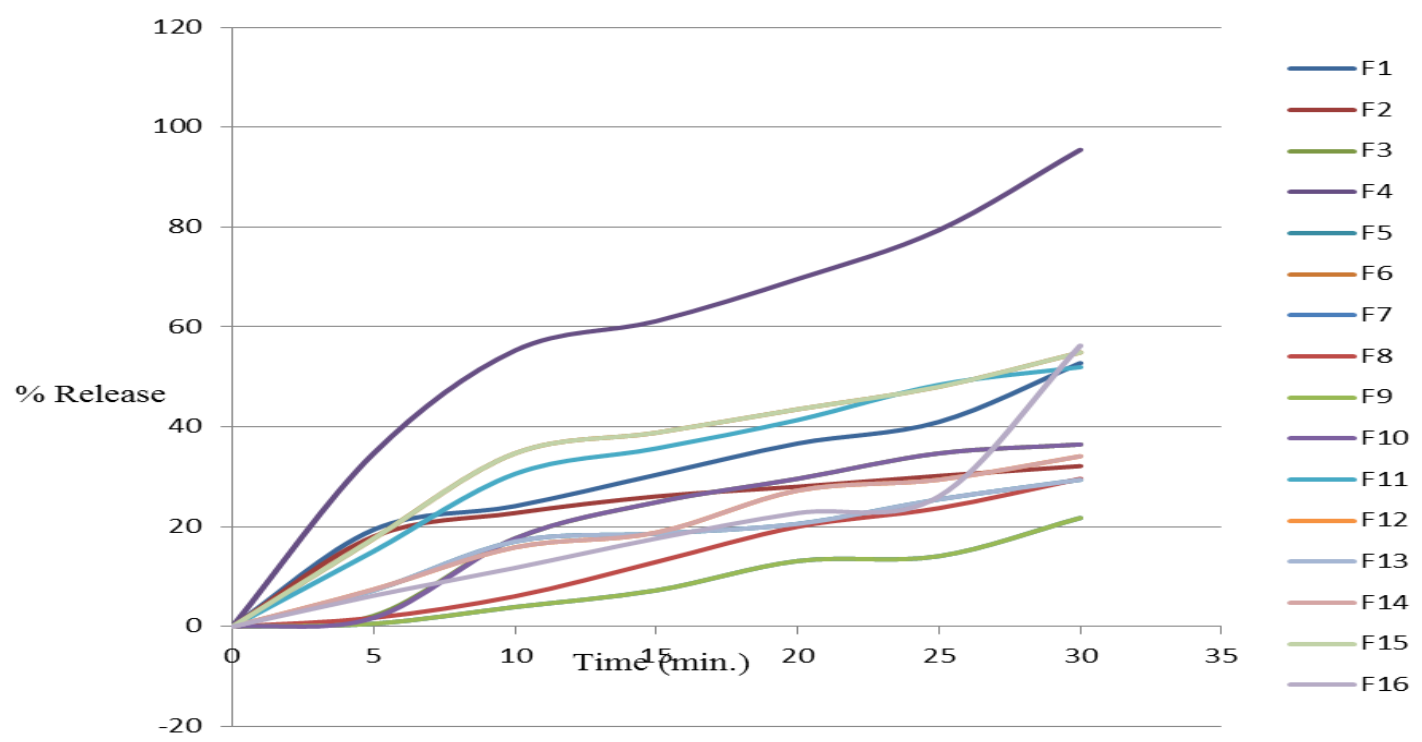

Figure 2a: Percent Drug Release of core tablets

The response surface graph figure $2 b$ shows that as the conc. of superdisentigrants and conc. of surfactant increases $\%$ drug release decreased. While with increase in superdisintegrant and decrease in surfactant conc increases the drug release.This might be due to high conc of surfactant drug may be entrapped in surfactant micelles.

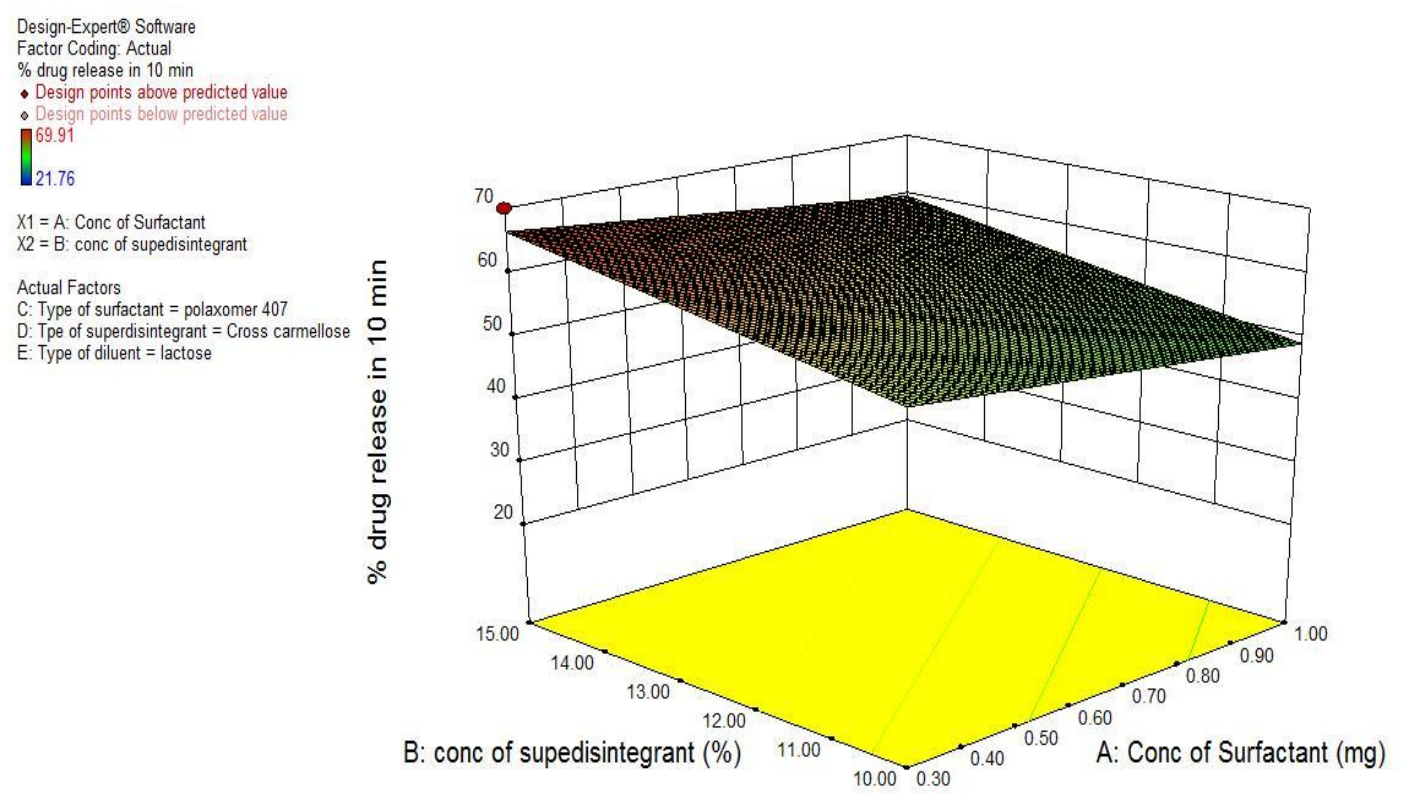

Figure 2b: Effect of superdisintegrants and surfactant on drug Release

\section{Postcompression Parameters of Press-Coated Tablets}

The tablet hardness, friability, weight variation of all tablet formulations were found to be satisfactory and reproducible as observed from the data in Table 7.The hardness of all the tablets was between 7 and $8 \mathrm{~kg} / \mathrm{cm}^{2}$. In the present study, the loss in total weight in friability test was in the range of 0.66 to $0.99 \%$ that indicates, the percentage friability for all the formulations was found below $1 \%$ indicating that friability $(\%)$ is within the acceptable limits. In a weight variation test, the pharmacopoeia limit for the percentage deviation for tablets weighing more than $100 \mathrm{mg}$ is $\pm 5 \%$. The average percentage deviation of all tablet formulations was found to be within limit, and hence all formulations passed the test for uniformity of weight as per official requirement. 
Table 7: Post-Compression Parameters for Press-Coated Tablets

\begin{tabular}{|c|c|c|c|c|c|}
\hline Formulations & $\begin{array}{c}\text { Hardness } \\
\left(\mathbf{K g} / \mathbf{c m}^{2}\right) \\
(\mathbf{n}=\mathbf{3})\end{array}$ & $\begin{array}{l}\text { Thickness } \\
(\mathbf{m m})(\mathrm{n}=3)\end{array}$ & $\begin{array}{l}\text { Diameter } \\
(\mathbf{m m})(\mathbf{n}=3)\end{array}$ & $\begin{array}{c}\text { Weight } \\
\text { Variation }(\%) \\
(\mathbf{n}=20)\end{array}$ & $\begin{array}{c}\text { Friability (\%) } \\
(\mathbf{n}=10)\end{array}$ \\
\hline F1 & $7 \pm 0.40$ & $6.17 \pm 0.027$ & $10.01 \pm 0.01$ & $122.39 \pm 1.2$ & 0.92 \\
\hline F2 & $7.5 \pm 0.27$ & $5.89 \pm 0.15$ & $10.00 \pm 0.02$ & $217 \pm 1.4$ & 0.86 \\
\hline F3 & $7 \pm 0.63$ & $5.93 \pm 0.26$ & $10.01 \pm 0.02$ & $175 \pm 1.1$ & 0.73 \\
\hline F4 & $7 \pm 0.28$ & $6.09 \pm 0.27$ & $10.02 \pm 0.02$ & $251.1 \pm 1.1$ & 0.77 \\
\hline F5 & $7.5 \pm 0.13$ & $5.97 \pm 0.15$ & $10.01 \pm 0.01$ & $246.17 \pm 1.7$ & 0.73 \\
\hline F6 & $8 \pm 0.45$ & $5.95 \pm 0.26$ & $10.00 \pm 0.02$ & $300 \pm 2$ & 0.68 \\
\hline F7 & $8 \pm 0.29$ & $6.13 \pm 0.17$ & $10.00 \pm 0.002$ & $100 \pm 1.5$ & 0.93 \\
\hline F8 & $7 \pm 0.28$ & $6.02 \pm 0.15$ & $10.01 \pm 0.01$ & $239.5 \pm 1.4$ & 0.88 \\
\hline F9 & $7 \pm 0.50$ & $5.89 \pm 0.15$ & $10.01 \pm 0.01$ & $122 \pm 1.1$ & 0.69 \\
\hline F10 & $7 \pm 0.40$ & $5.93 \pm 0.26$ & $10.00 \pm 0.02$ & $210.35 \pm 1.1$ & 0.82 \\
\hline F11 & $7.5 \pm 0.27$ & $6.09 \pm 0.27$ & $10.00 \pm 0.002$ & $250 \pm 1.1$ & 0.92 \\
\hline F12 & $7 \pm 0.63$ & $5.97 \pm 0.15$ & $10.01 \pm 0.01$ & $150 \pm 1.4$ & 0.77 \\
\hline F13 & $7 \pm 0.40$ & $5.93 \pm 0.26$ & $10.00 \pm 0.02$ & $210.35 \pm 1.1$ & 0.82 \\
\hline F14 & $7.5 \pm 0.13$ & $6.13 \pm 0.17$ & $10.01 \pm 0.02$ & $277.58 \pm 1.2$ & 0.81 \\
\hline F15 & $8 \pm 0.45$ & $6.02 \pm 0.15$ & $10.02 \pm 0.02$ & $155.5 \pm 1.2$ & 0.92 \\
\hline F16 & $8 \pm 0.29$ & $5.97 \pm 0.15$ & $10.01 \pm 0.01$ & $239.5 \pm 1.3$ & 0.97 \\
\hline F17 & $7 \pm 0.28$ & $6.09 \pm 0.27$ & $10.00 \pm 0.02$ & $189.25 \pm 1.3$ & 0.96 \\
\hline F18 & $7 \pm 0.50$ & $5.97 \pm 0.15$ & $10.00 \pm 0.002$ & $323.5 \pm 1.1$ & 0.72 \\
\hline F19 & $7 \pm 0.40$ & $5.95 \pm 0.26$ & $10.01 \pm 0.01$ & $294.25 \pm 1.6$ & 0.67 \\
\hline F20 & $7.5 \pm 0.27$ & $6.13 \pm 0.17$ & $10.01 \pm 0.01$ & $350 \pm 1.8$ & 0.69 \\
\hline F21 & $7 \pm 0.63$ & $6.02 \pm 0.15$ & $10.00 \pm 0.02$ & $321.79 \pm 1.4$ & 0.79 \\
\hline F22 & $7 \pm 0.28$ & $5.93 \pm 0.26$ & $10.00 \pm 0.002$ & $275 \pm 1.1$ & 0.88 \\
\hline F23 & $7 \pm 0.40$ & $5.95 \pm 0.26$ & $10.01 \pm 0.01$ & $294.25 \pm 1.6$ & 0.67 \\
\hline F24 & $8 \pm 0.45$ & $5.97 \pm 0.15$ & $10.00 \pm 0.002$ & $280 \pm 2.0$ & 0.69 \\
\hline F25 & $8 \pm 0.29$ & $5.95 \pm 0.26$ & $10.01 \pm 0.01$ & $158.5 \pm 1.9$ & 0.92 \\
\hline F26 & $8 \pm 0.45$ & $6.02 \pm 0.15$ & $10.02 \pm 0.02$ & $155.5 \pm 1.2$ & 0.92 \\
\hline F27 & $7 \pm 0.50$ & $6.02 \pm 0.15$ & $10.01 \pm 0.02$ & $282.25 \pm 1.0$ & 0.90 \\
\hline F28 & $7 \pm 0.28$ & $6.02 \pm 0.15$ & $10.01 \pm 0.01$ & $239.5 \pm 1.4$ & 0.88 \\
\hline F29 & $7.5 \pm 0.27$ & $5.93 \pm 0.26$ & $10.01 \pm 0.01$ & $200 \pm 1.5$ & 0.86 \\
\hline F30 & $7 \pm 0.63$ & $6.09 \pm 0.27$ & $10.00 \pm 0.02$ & $22.75 \pm 1.4$ & 0.87 \\
\hline F31 & $7 \pm 0.28$ & $5.95 \pm 0.26$ & $10.00 \pm 0.002$ & $251.1 \pm 1.1$ & 0.99 \\
\hline
\end{tabular}

The percent release of drug for all tablet formulations was found to be satisfactory and reproducible.

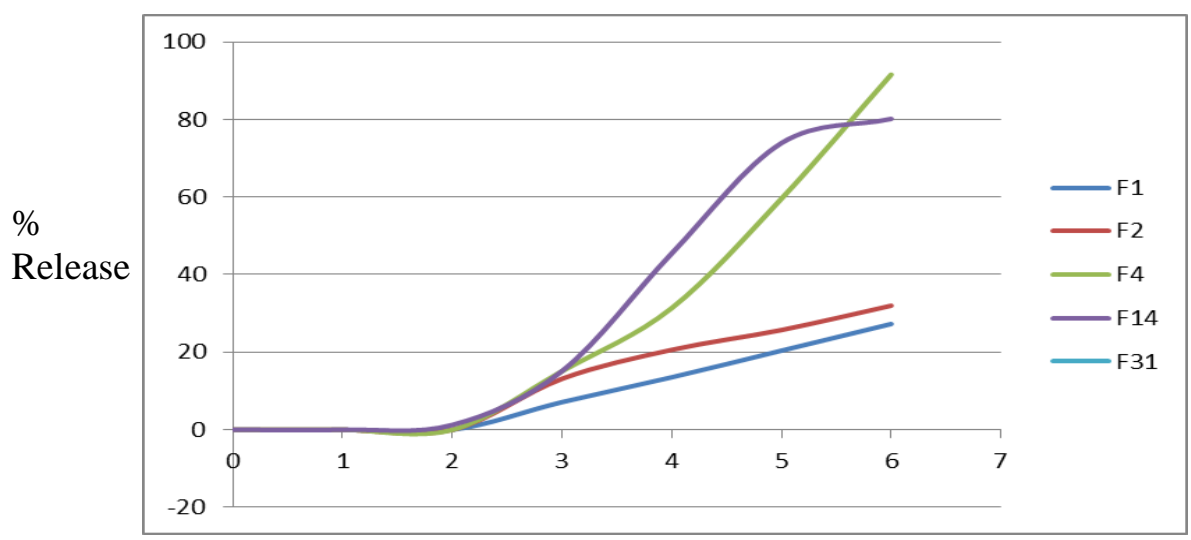

Time(Hrs.)

Figure 3a: Percent drug release of coated formulations \% Drug Release of coated formulations (Ethyl Cellulose and Polyox) 


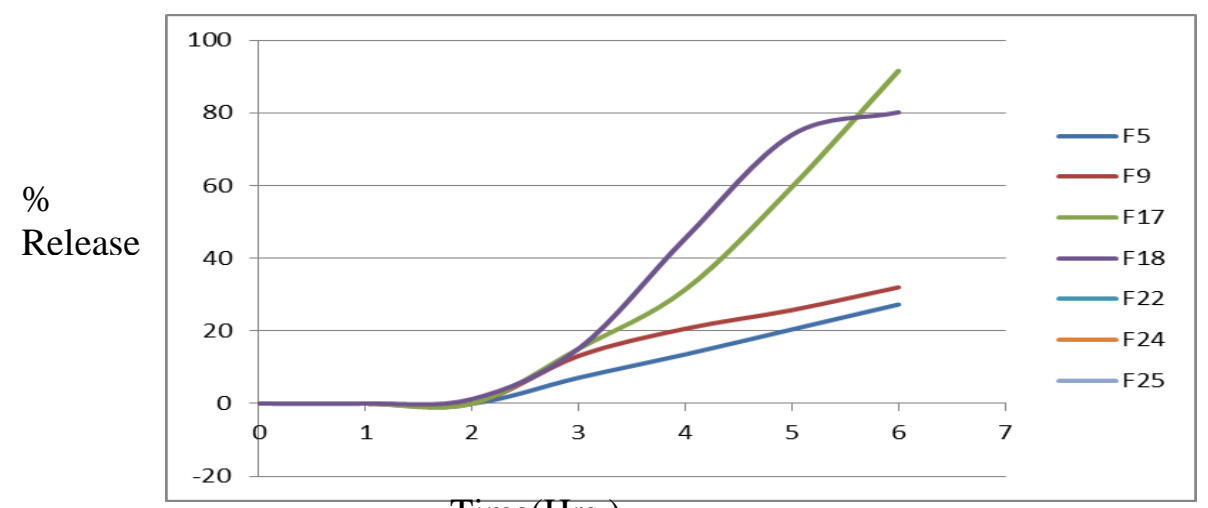

Time(Hrs.)

Figure 3b: Percent drug release of coated formulations (Ethyl Cellulose and Xanthan gum)

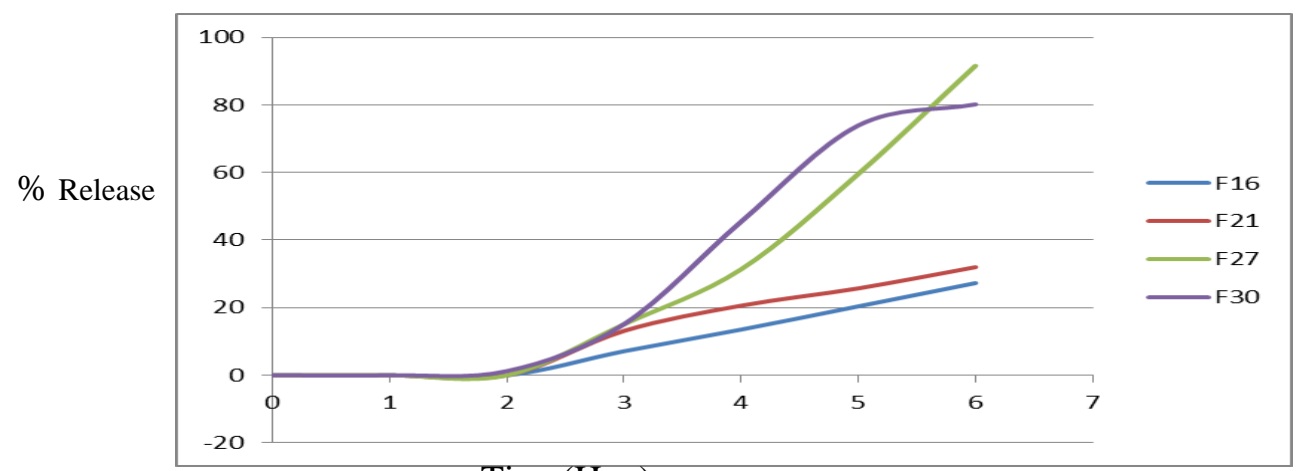

Time(Hrs.)

Figure 3c: Percent drug release of coated formulations (Ethyl Cellulose and HPMC)

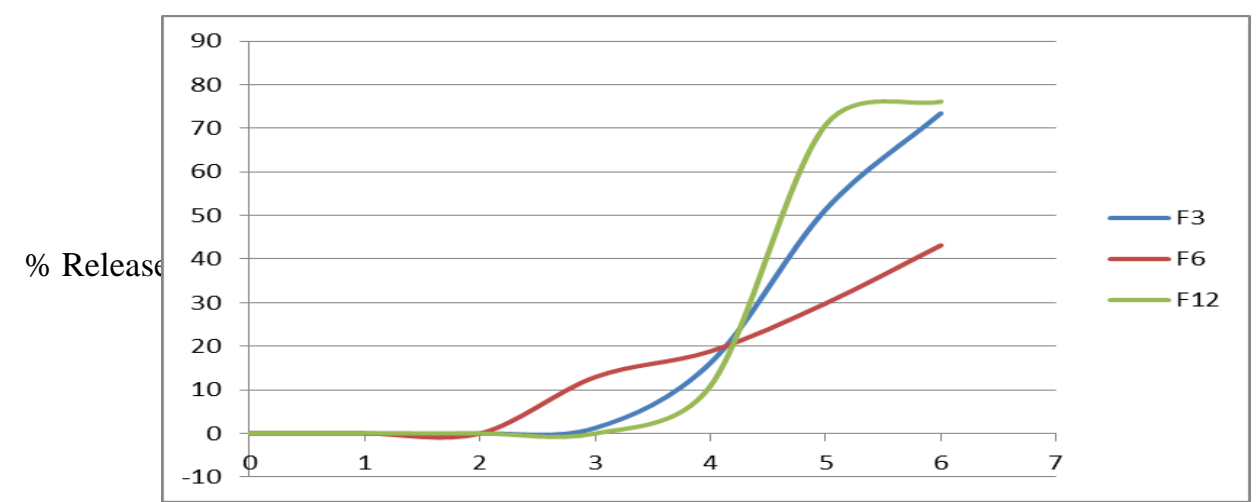

Time(Hrs.)

Figure 3d: Percentdrug release of coated formulations (Ethyl Cellulose and Polyox+ Xanthan gum)

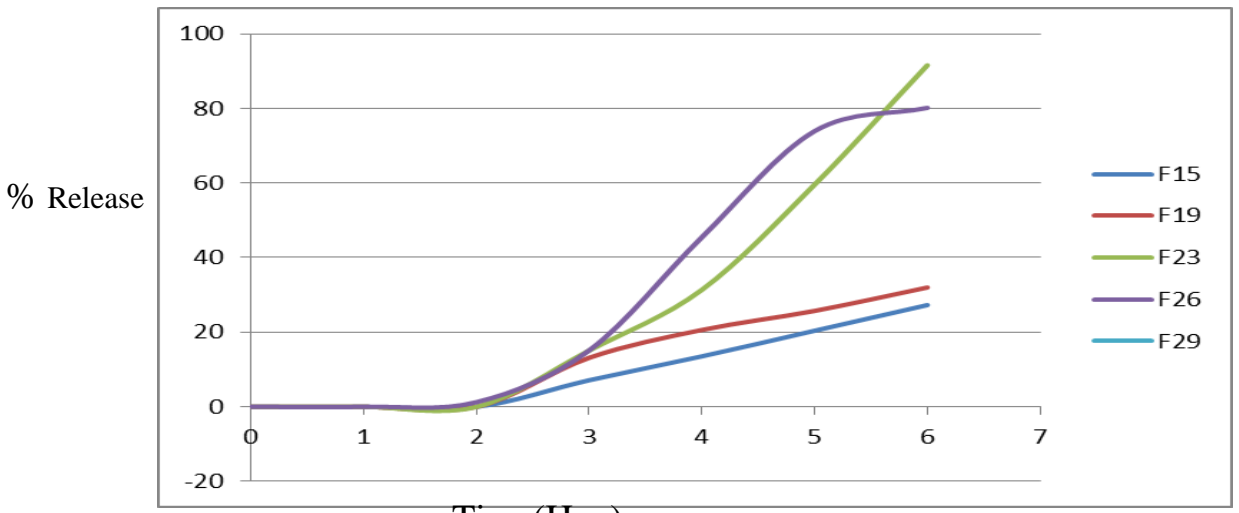

Time(Hrs.)

Figure 3e: Percent drug release of coated formulations (Ethyl Cellulose and Xanthan gum+ HPMC) 


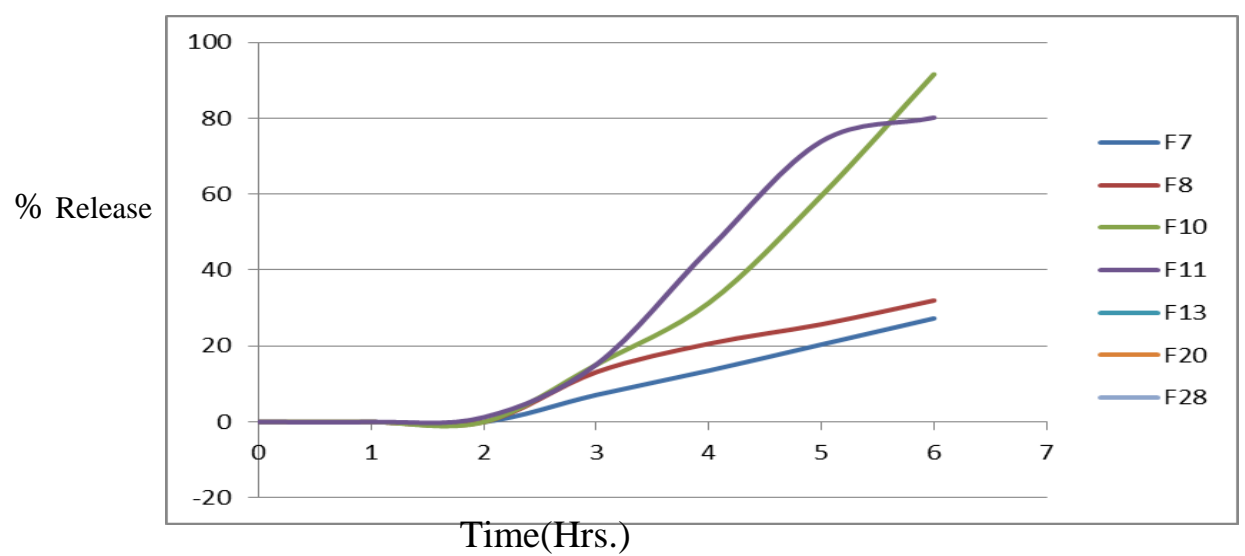

Figure 3f: Percent drug release of coated formulations (Ethyl Cellulose and HPMC+Polyox)

\section{Drug Release of coated formulations:-}

Lag time is the important criteria to deliver drug. In following formulations different polymers in different concentration were used.The coated tablet formulation consisting of ethyl cellulose and Polyox, ethyl cellulose and xanthum gum ,ethyl cellulose and HPMC achieved maximum 140 minutes, 175 minutes and 165minutes maximum lag time respectively( figure $(3 a, 3 b, 3 c))$. While the combination formulation consisting of ethyl cellulose, Polyox and xanthum gum, ethyl cellulose, xanthum gum and HPMC and ethyl cellulose, HPMC and Polyox achieved maximum 210 minutes, 170 minutes and 165 minutes Lag time respectively(Figure 3d,,3e,3f)). In this F12 formulation containing Xanthan gum, Polyox and ethyl cellulose combination showed the exact sigmoid curve and maximum lag time. Ethyl

\section{REFERENCES}

1. Jha N, Bapat S. Chronobiology and chronotherapeutics. Kathmandu University Medical Journal 2004; 2(8): 384-388.

2. Botti B, Youan C: Chronopharmaceutics: gimmick or clinically relevant approach to drug delivery, J. Control. Rel. 2004; 98(3): 337-353.

3. http://www.rxlist.com/singulair-drug/clinicalpharmacology.htm

4. Janugade B. U, Patil S. S., Patil S. V., Lade P. D.,Formulation And Evaluation Of Press-Coated Montelukast Sodium Tablets For Pulsatile Drug Delivery System. International Journal of Chemtech Research. 2009;1(3): 690-691.

5. Karavas E, Georgarakis E, Bikiaris D. Application of PVP/HPMC miscible blends with enhanced mucoadhesive properties for adjusting drug release in predictable pulsatile chronotherapeutics. Eur J Pharm. Biopharma 2006; (64): 11526.

6. Lu MF, Woodword L, Borodkin S. Xanthan gum and alginate based controlled release theophylline formulation. Drug Dev Ind Pharm 1991; 17(14): 1987-04. cellulose is hydrophobic in nature and Xanthan gum as per literature is known to prolong the drug release when it is combined with Polyox a water soluble high molecular weight resin the lag time is prolong for longer period of time.

\section{CONCLUSION}

Chronopharmaceutical Drug delivery formulations were prepared by direct compression press coating using Response Surface Methodology with polymers as Xanthan gum, Polyox, HPMC \& Ethyl Cellulose alone and in combination. Polyox having a property of fast hydration \& swelling useful for maintaining lag time. Xanthan gum has more viscosity on coming in contact with solvent and ethyl cellulose a hydrophobic polymer. So, combinations of these polymers give better lag time.

7. Neeraj Singh, Nisha, Vivek Gill, Parina Gill, Sukhbir Singh, International Research Journal of Pharmaceutical and AppliedSciences 2013; 3(4):84-87.

8. Rajalakshmi R, Aruna U, Vinesha V, Vardhan RV, Ramesh DR. Pulsatile drug delivery system: a novel approach for chronopharmacological disorders. IAJPR. 2013; 3(7): 51505162.

9. Lachman Leon, Lieberman Herbert A.; Pharmaceutical Dosage Forms: Tablets. In: The theory and Practice of Industrial Pharmacy; Lea and Febiger, U.S.A.; 3rd Edition; 1991, 293-345.

10. Liberman H.A, Lachman L, Schwartz J. B. Pharmaceutical Dosage Forms: Tablets. 1990; Vol 1, 131-188.

11. Liberman H. A, Lachman L, Schwartz J. B. Pharmaceutical Dosage Forms: Tablet. 1990; vol.- II, 2nd edition 1-104, 201338. 